\title{
ローラ式台上試験機を用いたペダル操作実験装置の作成
}

\section{Creation of pedal operation experimentation device using a flywheel type bench test machine}

\author{
○学 立松 宏美 (名城大院) 正 中島 公平（名城大） \\ 正 村上 好生 (名城大) 中村 英明 (愛知電機) \\ Hiroyoshi TATEMATSU, Kohei NAKASHIMA ,Yoshio MURAKAMI „Meijo University Graduate shool, 1-501, \\ Shiogamaguchi,Tenpaku,Nagoya 468-8502, Japan \\ Hideaki NAKAMURA, Aichi Electric Co.,Ltd ., 1,Aichicho,Kasugai-shi,Aichi 486-0933, Japan
}

Key Words: pedal operation experimentation device, flywheel type bench test machine

\section{1. まえがき}

近年減少傾向にある交通事故発生件数であるが, ペダルの 踏み間違い事故は, 統計を開始した 2004 年度から毎年 7000 件を推移し, 年間総死者・重軽傷者数 10000 人を超え, 大変 大きな事故発生件数である.

ブレーキペダルとアクセルペダルの踏み間違いによる事 故検証に対し, 大学の研究室等では PC 装置やフットスイッ チを用いたドライビングシミュレータを使用することがあ るが, この方式では運転姿勢, 振動, 走行音, ペダルの踏力 など実際の運転の感覚とは異なった状態であること．また， ドライビングシミュレータでは実車を運転している状態に 近い感覚を再現できる方式があるが, 費用の問題, 実験場所 の問題などから, 大がかりになる.

そこで, 本研究では, 実車の走行感覚の一部をとり入れた ペダル操作の検証に供することを目的としたローラ式台上 試験機, 及び計測機器の設計・製作を行った.この装置を用 いて人はどのような状態で, またどのような車の構造の場合 に踏み間違いが生じやすいのかなどの検証を行いたい.

\section{2. オートマチックトランスミッション搭載車両}

ペダル踏み間違い事故の大多数はオートマチックトラン

スミッションを搭載した車両が多く普及している日本, アメ リカ合衆国に多くみられ, マニュアルトランスミッションを 搭載した車両が多く普及しているヨーロッパではペダル踏 み間違い事故は少ない。

この点から，実験にはオートマチックトランスミッション を搭載した前輪駆動方式の 4 輪軽自動車を使用した. 加速動 カ計上に設置されたオートマチックトランスミッション搭 載車両を Fig. 1 に示す.

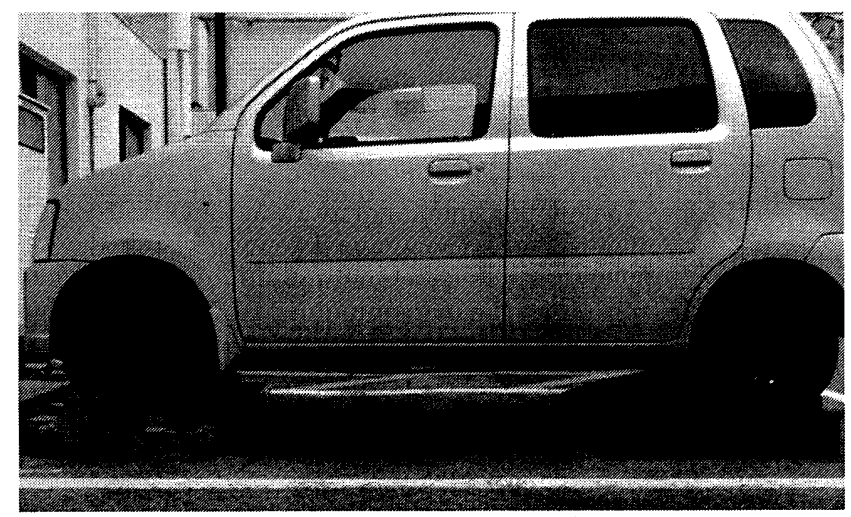

Fig.1 Automatic Transmission Car

\section{3. 加速動力計の製作}

台上試験機を製作するにあたって，小径駆動ローラを使用 した比較的小型の台上試験機を製作することとした．また， 加速時における車の走行抵抗は加速抵抗が $80 \%$ 以上を占め ていることから, 加速抵抗と同等の負荷を台上試験で作り出 すことで走行状態を再現する. 製作した台上試験機（加速動 力吸収計）をFig. 2 に示す1)。

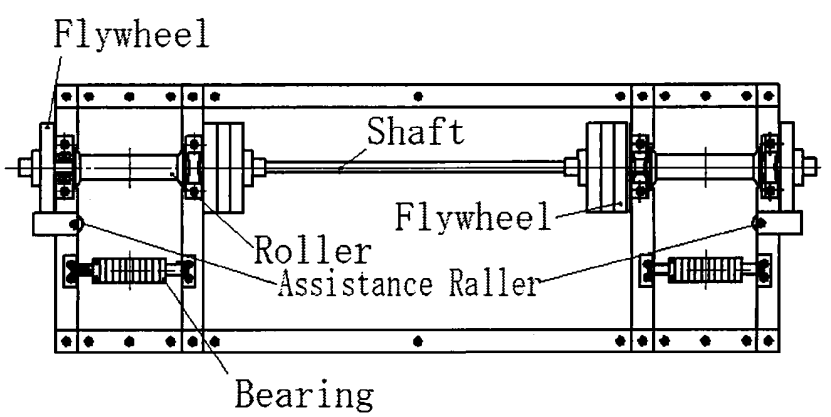

Fig.2 Flyweel type bench test machine

\section{4. 実験方法}

実験では，自動車用信号機に見立てた 3 色 LED（赤色， 青色，黄色）を使用した信号機を車両前方に配置する. LED 信号機（Fig.3）は任意時閒間隔に点灯させ被験者には青色 LED 点灯の場合アクセルペダル, 赤色 LED 点灯の場合はブ レーキペダルを踏む動作を行う．被験者（運転者）が信号機 の点灯に気づきアクセルペダルから足を動かすまでを「認知 時間」，アクセルペダルから足が離れた瞬間からブレーキペ ダルに足が接触するまでを「踏み変え時間」として計測する. この時, 認知時間と踏み変え時間の計測に際してはデータロ ガ, ハイスピードカメラを使用した.

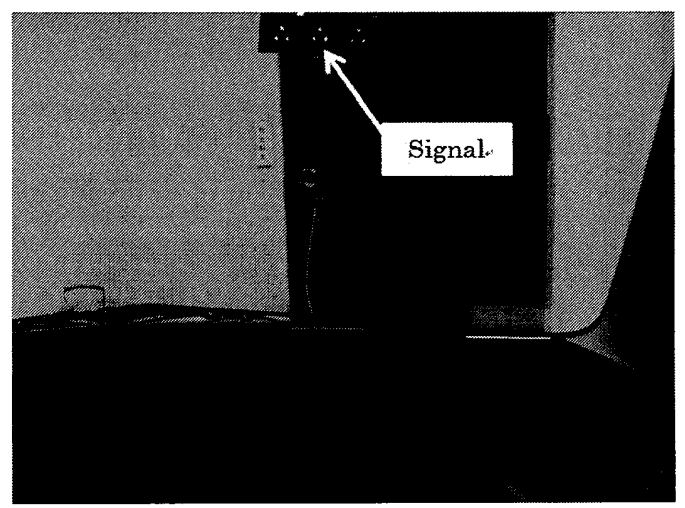

Fig.3 3-color LED signal 


\section{5. 計測方法}

Fig.4 に示しているような各装置を使用して実験（運転， ペダル操作，時間計測等）を行った. 被験者の認知時間, 踏 み変え時間を記録するために，床，アクセルペダル，ブレー キペダルにセンサを取り付けデータロガを接続し記録する. また，実験中の被験者のペダル動作，足動作を記録するため にハイスピードカメラを併用した.

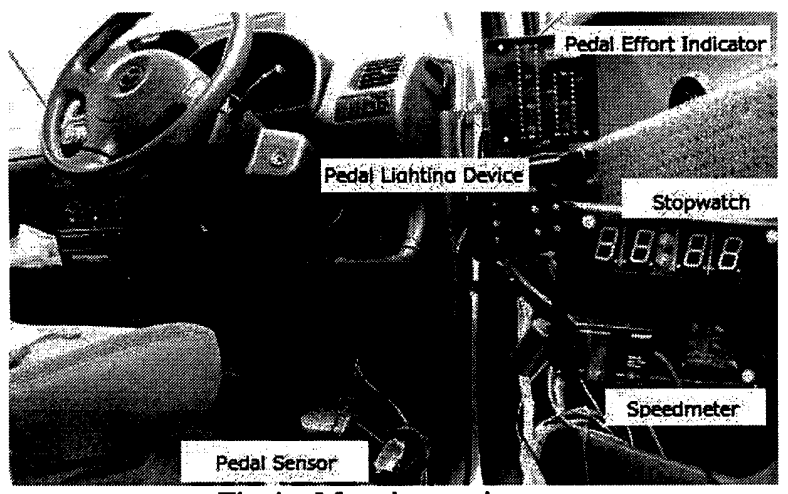

Fig.4 Metering equipment

\section{6. 実験装置補機}

運転に供する加速動力計本体とは別に，ペダル操作実験を 行うために使用した実験装置補機について説明する.

\subsection{3 色 LED 信号機}

被験者にアクセルペダルとブレーキペダル操作の指示を 与えるために信号機を作成し，高さ $1650 \mathrm{~mm}$ の位置に 3 色 LED を右から赤色, 黄色, 青の順番に取り付けた（Fig.3）.

\section{2 ハイスピードカメラ}

実験中の記録，実験検証には，被験者のペダル動作，反応 時間, 踏み変え時間の記録を正確に計るため, 時間当たり描 写枚数を多く記録できるカメラとして, 最大 $1200 \mathrm{fps}$ の動画 を記録可能なカシオ計算機株式会社の EX-F1 を使用した.

\section{3 ストップウォッチ}

ペダル操作の踏み変え動作時間を計るために設置したス トップウォッチは最小 0.01 秒まで刻むことが可能な自作品 を用いた。

\section{4 スピードメータ}

ペダル操作時のタイヤの回転速度を計測するためにスピ ードメータを設置した. カメラの設置場所の制限から, 自動 車に設置されているスピードメータではカメラに映しだす ことが困難なため, ピボット製のスピードメーターVを使用 した（本体サイズ $=51 \times 35 \times 22 \mathrm{~mm}$ ).

\section{5 ペダルセンサ，床センサ}

運転者が指示に気づきブレーキペダル，アクセルペダル， 床センサを踏んだ際に, データロガへ出力するためのペダル センサ，床センサを作成した。

\section{6 ペダル連動表示装置}

被験者がアクセルペダル,ブレーキペダルを踏んだ際に連 動して点灯する状態をカメラに写し出させるように装置を 設けた。

\section{7 ペダル踏力表示装置}

被験者のアクセルペダル，ブレーキペダル崉力を測定する ため, D-Rights 社製のドライビングモニターを設置, これに
よって最大 10 段階の踏力変化の表示を可能にした.

\section{8 拘束器具}

中高齢者のペダル動作を再現するため, 被験者に膝，足首 を拘束した. 膝を自作の拘束器具とサポーターを使用し，足 首には金属板を長靴の内部に沿ってはめ込むことにより関 節の動きを大幅に規制することを可能にした.

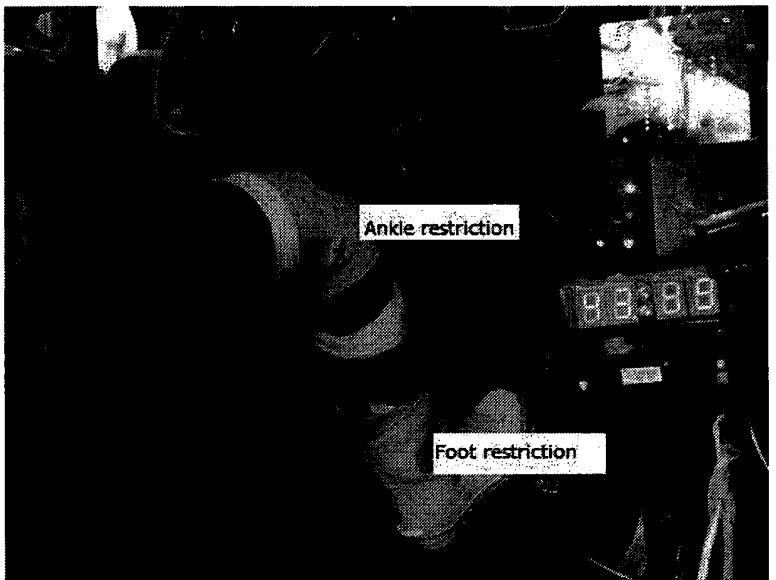

Fig.5 Restriction

7. シミュレーション装置

実車ペダル実験を行う上で，PC 装置を使用した室内シミ ユレーション装置を実車装置と比較をするために作成した. シミュレーション装置を使用するにあたり，実車との位置関 係は同じ状態にしている.

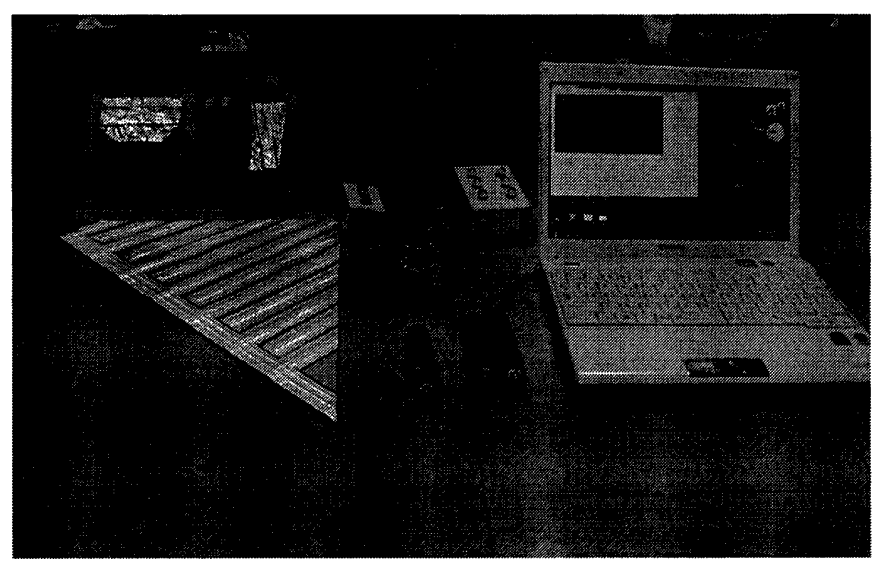

Fig. 6 Simulation equipment

\section{8. 結言}

実車実験を行うにあたり必要な実験器具の設計・作成を行 ってきた. 初期の段階ではハイスピードカメラで被験者のペ ダル操作を撮影していたが, データロガを使用したことで実 験記録の精度向上を計った. 今後更なる精度向上のためにス ピードメータやペダル踏力表示装置（実験装置補機）をデー タロガ内に記録できるようにする．また，実車実験とシミュ レーション装置を使用した場合の比較を行い, 実験結果にど のような変化が現れるのかを示していきたい.

参考文献

1) 村上, 中村, 中島, 横森,「ペダル操作実験用ローラ式 台上試験機の設計・製作」日本機械学会東海支部 No, 113-1, 406 (2011) 